ANUVA Volume 2 (4): 337-345, 2018

Copyright @2018, ISSN: 2598-3040 online

Available Online at: http://ejournal.undip.ac.id/index.php/anuva

\title{
Materi Pokok dalam Literasi Media Sosial sebagai salah Satu Upaya Mewujudkan Masyarakat yang Kritis dalam Bermedia Sosial
}

\author{
Roro Isyawati Permata Ganggi ${ }^{1 *}$ \\ ${ }^{\text {I} P r o g r a m ~ S t u d i ~ I l m u ~ P e r p u s t a k a a n, ~ F a k u l t a s ~ I l m u ~ B u d a y a, ~ U n i v e r s i t a s ~ D i p o n e g o r o, ~}$ \\ Jl. Prof. Soedarto, SH, Kampus Undip Tembalang, Semarang, Indonesia \\ $\left.{ }^{*}\right)$ Korespondensi: isya.ganggi@gmail.com
}

\begin{abstract}
[Title: Subject Matter in Social Media Literacy as One of the Efforts Embody a Critical Community in Using Social Media] Social media is one of the most internet service widely used by internet users at this time. The ease of interaction and disseminate information is the main attraction of this service. However, the ease of interacting and spreading such information also have a negative impact on the current, that many hoax are released. Social media literacy needs to be given in order to create community-based information and knowledge. As profession, librarian has a strong literacy background, already duly seeks the formation of a society that is critical in the use of social media through social media literacy. One of the efforts to form a community that is critical in the use of social media is to run workshops that have had subject matters which has a same standard. The subject matters should be included in social media literacy workshops are: (1) Think before doing the post; (2) what should be posted and when it can be done; (3) How your post so that it can be found. The three of subject matters must go into social media literacy material because this material is an attempt to build a society that is critical in the use of social media.
\end{abstract}

Keywords: critical societies; social media literacy; subject matters of social media literacy

\begin{abstract}
Abstrak
Media sosial merupakan salah satu layanan internet yang paling banyak digunakan oleh para pengguna internet pada saat ini. Kemudahan dalam berinteraksi dan menyebarkan informasi merupakan daya tarik utama dari layanan ini. Namun, kemudahan dalam berinteraksi dan menyebarkan informasi tersebut juga memiliki dampak negatif pada saat ini, yaitu banyak beredarnya berita hoax. Literasi media sosial perlu diberikan dalam rangka menciptakan masyarakat berbasis informasi dan pengetahuan. Pustakawan sebagai salah satu profesi yang memiliki latar belakang literasi yang kuat sudah sepatutnya mengupayakan pembentukan masyarakat yang kritis dalam bermedia sosial melalui literasi media sosial. Salah satu upaya membentuk masyarakat yang kritis dalam bermedia sosial adalah dengan menjalankan workshop yang telah memiliki materi pokok yang diseragamkan. Materi pokok yang sebaiknya dimasukkan dalam workshop literasi media sosial adalah: (1) Berfikir sebelum melakukan post; (2) Apa yang harus dipost dan kapan dapat dilakukan; (3) Bagaimana supaya post anda dapat ditemukan. Ketiga kemampuan ini harus masuk ke dalam materi pokok literasi media sosial karena materi pokok ini merupakan upaya untuk membangun masyarakat yang kritis dalam bermedia sosial.
\end{abstract}

Kata kunci: masyarakat kritis; literasi media sosial; materi pokok literasi media sosial

\section{Pendahuluan}

Seiring dengan perkembangan perkembangan teknologi, informasi telah menjadi salah satu kebutuhan manusia. Adanya penemuan internet merupakan salah satu hal yang mempengaruhi kebutuhan manusia terhadap informasi. Berdasarkan data dari Internet Live Stats pada tahun 2014 Indonesia dalam hal pemanfaatan internet menempati urutan ke 13 dunia dengan total pengguna sebesar 42.258 .824 
(Internet Live Stats, 2014). Sedangkan, hal yang paling banyak diakses oleh pengguna di internet di Indonesia adalah media sosial, pesan instan, membaca berita, mencari data, dan streaming video (APJII, 2015).

Media sosial merupakan salah satu layanan di internet yang banyak diakses oleh para pengguna internet (netizen). Media sosial menjadi salah satu ajang berinteraksi bagi para netizen di dunia maya. Tidak hanya sebagai ajang berinteraksi, media sosial juga menawarkan suatu wadah untuk menyebarluaskan informasi baik informasi mengenai diri sendiri maupun informasi yang bersifat umum. Informasi dalam media sosial disebarkan dengan cara memberikan tag sesama pengguna maupun dengan cara share informasi atau dengan memberi hashtag.

Penyebaran informasi yang terjadi di media sosial sangatlah cepat mulai dari informasi yang bersifat trivia sampai informasi yang berbau SARA. Tak jarang berkat adanya sharing informasi di media sosial suatu permasalahan menjadi ter-blow up dan akhirnya menjadi pusat perhatian di dunia maya. Terkadang, penyebaran informasi di media sosial juga berpotensi menimbulkan polemik. Contoh paling dekat yang kita alami adalah pada saat pemilihan umum tahun 2014 yang lalu. Betapa besar peran media sosial dalam menggiring opini masyarakat.

Banyaknya informasi yang disebarkan di media sosial membuat penggunanya harus lebih berhatihati. Apakah informasi tersebut merupakan fakta, opini, atau hanya informasi yang dibuat dengan tujuan tertentu. Di sinilah para pengguna media sosial perlu memiliki keterampilan literasi media sosial. Literasi media sosial telah banyak diperbincangkan. Hal ini dikarenakan dampak dari penggunaan media sosial yang begitu besar dalam upaya penggiringan opini masyarakat. Sosialisasi mengenai literasi media sosial banyak didengungkan dari profesi pustakawan.

Literasi media sosial perlu diberikan dalam rangka menciptakan masyarakat berbasis informasi dan pengetahuan. Pustakawan sendiri merupakan profesi yang bersinggungan langsung dengan informasi, baik informasi tercetak maupun elektronik. Sedangkan media sosial juga merupakan salah satu wahana dalam memperoleh informasi. Di sinilah pustakawan diperlukan sebagai salah satu upaya mencipatakan masyarakat yang literasi.

\section{Perpustakaan dan Internet}

Internet merupakan salah satu produk dari teknologi informasi. Internet pada awalnya dimanfaatkan hanya dalam bidang militer. Internet menjadi semakin mendominasi dalam teknologi informasi semenjak ditemukannya World Wide Web. World Wide Web atau yang lebih dikenal dengan www atau web merupakan suatu ruang informasi dimana dokumen dan sumber daya web lainnya diidentifikasi oleh URL, di-interlink-an oleh link hypertext, dan dapat diakses melalui internet. Fitur yang paling dasar dari web sendiri seperti dikutip dalam Rao dan Babu (2001) adalah sebagai berikut: 
a. Mendukung pendistribusian informasi dalam beberapa situs yang berbeda di seluruh internet.

b. Kapasitas untuk menggabungkan semua jenis objek media (video, suara, gambar, teks, dll) ke dalam satu dokumen.

c. Pemanfaatan arsitektur berbasis hypertext atau hypermedia yang mana dokumen telah melekatkan link ke dokumen lain, yang ada baik secara lokal atau dimanapun di dunia.

d. Kemampuan untuk menjangkau kedalaman dari klien heterogen atau server platforms. Salah satunya dapat melihat dari berbagai client platform (DOS, UNIX, dll) objek data tersimpan secara virtual di berbagai platform server yang mendukung hampir semua jenis protokol misalnya Email (Simple Mail Transfer Protocol), Telnet (Telnet Protocol), FTP (File Transfer Protocol), USENET (Network News Transfer Protocol), Gopher (Gopher Protocol) dan Web pages (HyperText Transfer Protocol).

e. Kemampuan untuk mendukung kontruksi sumberdaya informasi di seluruh internet.

f. Merevolusi cara orang dalam mengakses informasi, dan membuka kemungkinan baru di bidang lain seperti perpustakaan digital, perpustakaan virtual, temu kembali dan diseminasi informasi ilmiah, pendidikan, perdagangan, hiburan, pemerintahan, dan perawatan kesehatan.

Pada dasarnya fitur yang ditawarkan oleh internet yaitu adalah untuk akses informasi. Perpustakaan pun memiliki fungsi yang sama pada saat ini, yaitu untuk akses informasi. Mengingat akan adanya hal tersebut maka sudah pasti pustakawan tidak hanya dituntut dapat memberikan informasi secara tercetak tetapi juga informasi yang ada dalam bentuk elektronik di internet. Maka dari itu pustakawan perlu memiliki keterampilan untuk dapat melakukan temu kembali informasi di internet.

Dewasa ini perpustakaan sudah bersinergi dengan internet. Hal ini diwujudkan dengan adanya perpustakaan digital dan perpustakaan virtual. Adanya perpustakaan digital dan perpustakaan virtual merupakan salah satu bukti bahwa pustakawan haruslah dapat memanfaatkan internet sebagai penunjang kinerja. Perpustakaan yang masih memiliki bentuk fisikpun menggunakan jasa layanan internet untuk berbagi informasi dalam rangka memberikan layanan prima kepada pemustaka.

\section{Pustakawan dan Media Sosial}

Perpustakaan memanfaatkan internet baik sebagai penunjang kegiatan sehari-hari, berbagi informasi, maupun untuk pengembangan layanan untuk kepuasan pemustaka. Layanan internet bahkan termasuk media sosial dewasa ini sudah marak dimanfaatkan oleh perpustakaan untuk mempromosikan perpustakaan maupun membangun interaksi yang lebih intensif dengan para pemustaka. Hal ini dilakukan oleh pemustaka karena saat ini media sosial seakan-akan sudah menjadi suatu media yang melekat di masyarakat pengguna internet.

Hampir setiap pengguna internet (netizen) pasti memiliki akun di beberapa media sosial. Pemanfaatan media sosial di Indonesia memang cukup tinggi. The Wall Street Journal mencatat bahwa 
pengguna media sosial facebook di Indonesia pada bulan Juni 2014 sudah mencapai angka 69 juta, sedangkan pengguna Twitter mencapai 50 juta (Prihadi, 2015). Banyaknya pengguna media sosial menunjukkan bahwa media sosial sudah menjadi kebutuhan sehari-hari.

Media sosial sudah sangat melekat dengan netizen, sehingga masyarakat perlu memiliki keterampilan supaya menjadi konsumen media sosial yang kritis. Animo yang besar terhadap media sosial juga merambah pustakawan. Bahkan Virginia Power Graduate Tutor in Information Management, University of the West of Egland (Taylor \& Francis Online, 2014) memberikan akronim untuk media sosial yaitu:

\section{Sharing views}

2. Optimizing knowledge

3. Collaborating on projects

4. Investigating new ideas

5. Advocacy for your service provision

6. Learning from others

7. Making new connections

8. Enhancing your practice

9. Debating the future

10. Inspirational support

11. An essential tool for your information toolbox

Akronim di atas menunjukkan bahwa sebenarnya media sosial dapat sangat bermanfaat bagi perkembangan ilmu pengetahuan. Sayangnya, saat ini media sosial justru dipenuhi informasi yang simpang siur. Pada akhirnya muncul pertanyaan tentang siapa yang bertanggung jawab dalam mengajarkan keterampilan menjadi konsumen media sosial yang kritis.

Dalam hal ini pustakawan berada pada situasi yang unik, dengan fondasi yang kuat dalam literasi informasi, untuk memandu dan mengintruksikan masyarakat untuk menjadi konsumen media sosial yang kritis. Tujuannya adalah untuk memberikan kesadaran kepada masyarakat bahwa informasi yang diunggah ke media sosial mungkin saja memiliki dampak bagi mereka dikemudian hari.

\section{Literasi Media Sosial}

Literasi media sosial merupakan salah satu bentuk khusus literasi informasi secara umum. Literasi media sosial merupakan turunan dari literasi media, yang merupakan turunan dari literasi informasi. Seseorang yang terlatih dalam mengaplikasikan sumber informasi dalam menyelesaikan pekerjaan mereka dapat disebut orang yang melek informasi (Manchester Metropolitan University, 1). Literasi media sosial sendiri dapat berarti keterampilan seseorang dalam mencari, memilah, dan mengaplikasikan 
sumber informasi di media sosial. Orang yang melek informasi di media sosial akan menjadi orang yang kritis ketika mendapati informasi hoax. Masyarakat yang melek informasi di media sosial akan sulit untuk diadu domba karena kepentingan tertentu.

Literasi media sosial merupakan turunan dari Information Literacy Competency Standards Association of College and Research Libraries (ACRL) dari poin "Use information effectively to accomplish a specific purpose" (ACRL, 2000). Pada poin ke lima dari standar ACRL tersebut orang yang literasi dituntut untuk dapat menggunakan informasi secara efektif untuk menyelesaikan tujuan spesifik. Secara sederhana literasi media sosial dijabarkan dalam lima konsep oleh Stacey Goodman (2014):

1. Seluruh media pesan dikontruksi

Di media sosial banyak orang mengunggah gambar dengan tulisan (meme). Tulisan pada gambar tersebut merupakan perintah untuk kita dalam menerjemahkan gambar tersebut. Hal ini merupakan salah satu contoh bahwa pesan di media sosial merupakan sesuatu yang dapat dikontruksi. Tidak jarang beberapa informasi hanya diberikan setengah, sehingga memberikan ambiguitas persepsi.

2. Pesan media membentuk persepsi kita akan suatu realita

Contoh paling dekat dalam kasus ini adalah penggunaan media sosial pada saat pemilihan presiden 2014 lalu. Media sosial berperan besar dalam membentuk opini masyarakat terkait kedua kandidat presiden. Tak jarang suatu kejadian menjadi pusat perhatian masyarakat karena pada awalnya informasi tersebut dibagikan di media sosial dan kemudian menjadi viral.

3. Berbeda audiens, berbeda pula cara memahami pesan yang sama

Salah satu fitur yang banyak digunakan di media sosial adalah "share". Fitur ini memungkinkan pengguna berbagi suatu informasi kepada pengguna lain. Mereka mungkin lupa bahwa tidak semua pengguna memiliki pengetahuan mengenai berita yang kita bagi. Hal ini dapat menyebabkan penafsiran ganda, sehingga memicu adanya konflik.

4. Pesan media memiliki dampak komersial

tak jarang ketika akan mengunduh suatu informasi pengguna diminta memasukkan akun media sosial atau email. Hal ini terlihat sepele tetapi sebenarnya informasi data diri dapat diperjualbelikan.

5. Pesan media melekatkan sudut pandang

ketika pengguna membuat status tentu yang diharapkan adalah pengguna lain dapat memahami apa yang ia rasakan. Semisal, ketika pengguna mengunggah foto liburannya, ia ingin pengguna lain tahu bahwa ia menemukan tempat yang indah.

Konsep literasi media sosial di atas memberikan gambaran bahwa media sosial sangatlah berperan dalam membentuk opini seseorang. Besarnya dampak media sosial tersebut membuat seseorang harus 
mampu memilah dan memilih informasi mana yang merupakan fakta dan mana yang merupakan opini. Rheingold (Crook, 2012) mendiskusikan ada lima cara untuk dapat meliterasi media sosial:

1. Perhatian

Kemampuan untuk mengidentifikasi ketika dibutuhkan fokus perhatian dan mengenali ketika multitasking bermanfaat. Perhatian dapat dicapai dengan memahami bagaimana pemikiran orang. Akan sulit untuk memfokuskan perhatian karena pikiran kita cenderung berjalan acak.

2. Partisipasi

Mengetahui kapan dan bagaimana partisipasi merupakan hal penting. Partisipasi memberikan pengguna pengalaman berbeda saat menjadi produktif. Partisipasi dalam media sosial dibedakan menjadi dua yaitu netizen aktif dan netizen pasif. Netizen aktif merupakan pengguna media sosial yang ikut memberikan post di media sosial. sedangkan pengguna pasif merupakan pengguna media sosial yang hanya membaca lini masa media sosial tanpa memberikan posting-an.

3. Kolaborasi

Pengguna dapat mencapai lebih dengan bekerja sama dibandingkan dengan bekerja sendirian. Melalui kolaborasi, redudansi dapat dihilangkan dan pekerjaan dapat didistribusikan. Adanya kolaborasi memungkinkan masyarakat berbagi sumber daya dan membangun ide lain.

4. Kesadaran jaringan

Jaringan sosial saat ini diperluas dengan adanya teknologi. Saat ini masyarakat dapat menjadi anggota dari newsgroup, komunitas virtual, situs gossip, forum dan organisasi lainnya. Pemahaman mengenai sosial dan jaringan teknis.

5. Pemakaian secara kritis

Pemakaian secara kritis adalah evaluasi tentang apa dan siapa yang dapat dipercayai. Sebelum mempercayai, mengkomunikasikan, atau menggunakan apa yang ditulis oleh orang lain, ada baiknya melakukan identifikasi. Cek klaim yang terdapat dalam informasi tersebut, lihatlah latar belakang penulis, sumber daya dan keakuratannya.

\section{Materi Pokok dalam Literasi Media Sosial}

Berdasarkan penjelasan di atas pustakawan tentulah menjadi pihak yang tepat untuk mengajarkan literasi media sosial kepada masyarakat umum. Di perpustakaan daerah maupun perpustakaan kota, pustakawan perlu memberikan seminar atau workshop untuk para pemustaka. Seminar atau workshop ini dapat diberikan pada saat pendidikan pemakai atau secara mandiri.

Adanya seminar mengenai literasi media sosial diharapkan mampu menciptakan masyarakat yang melek informasi. Masyarakat yang cerdas dalam menggunakan media sosial diharapkan mampu meminimalisasi adanya dampak negatif dari media sosial. Pustakawan mampu melakukan peran ini 
karena mereka memiliki dasar literasi informasi yang merupakan keterampilan umum dalam hal informasi.

Sebelum memberikan pendidikan literasi media sosial, pustakawan perlu membuat materi pokok. Materi pokok diperlukan supaya pengajaran literasi media sosial lebih terarah dan terorganisasi. Pembuatan materi pokok dapat disandarkan pada suatu standar literasi informasi yang kemudian dikembangkan sendiri. Pustakawan juga perlu memperhatikan kapan sekiranya materi pokok tersebut diperbarui. Hal ini perlu diperhatikan karena perkembangan jenis media sosial sangatlah cepat.

Materi pokok pengajaran literasi media sosial mungkin saja berbeda-beda untuk setiap perpustakaan. Tetapi setidaknya pustakawan haruslah dapat memahamkan pemustaka akan cara untuk bermedia sosial dengan benar, yaitu:

1. Berfikir sebelum melakukan post

Dalam tahapan ini ada beberapa langkah yang dapat diterapkan. (1) Sebelum mengunggah suatu posting-an sebaiknya pengguna media sosial mengatur rencana sebelumnya. Apakah media sosial yang dimiliki akan digunakan untuk berhubungan dengan pengguna lain atau untuk mengumumkan suatu informasi. (2) Mengetahui apa yang dapat digunakan untuk menyelesaikan suatu tugas, akan membantu dalam memformulasikan apa, kapan, dan bagaimana tindakan anda di media sosial. (3) Bagaimana cara mengukur kesuksesan dalam bermedia sosial? apakah diukur dengan banyaknya like, retweet atau follower. (4) Meluangkan waktu untuk memikirkan apa yang ingin dilakukan dan bagaimana mengetahui bahwa kesuksesan tersebut akan sangat bermanfaat nantinya.

2. Apa yang harus dipost dan kapan dapat dilakukan

Cara terbaik dalam memposting suatu informasi adalah melakukannya secara konsisten. Sebenarnya disini pustakawan perlu menekankan bahwa masyarakat perlu melakukan posting yang berimbang. Masyarakat perlu mengetahui seluk beluk informasi sebelum mengunggah suatu informasi. Penekanan bahwa ketika mengunggah sesuatu di media sosial pada akhirnya menjadi konsumsi publik juga diperlukan. Hal ini mengacu pada poin berfikir sebelum melakukan post.

3. Bagaimana supaya post anda dapat ditemukan

Tujuan melakukan post adalah supaya orang lain mengerti apa yang sedang kita fikirkan atau kita rasakan. Membuat jejakan supaya suatu post dapat dipanggil kembali juga merupakan hal yang penting. Tujuan lainnya untuk menghindarkan dari melakukan post yang tidak bertanggungjawab. Saat ini jejakan yang digunakan di beberapa media sosial adalah hashtag dengan tanda pagar (\#). Hashtag digunakan untuk dapat mengelompokkan informasi sesuai dengan temanya, selain itu juga untuk menemukembalikan informasi.

Pustakawan dalam mengajarkan literasi media membuat profesi pustakawan semakin terlihat dinamis. Profesi pustakawan bahkan mampu mengatasi kesimpangsiuran informasi di media sosial yang 
meskipun dianggap sepaele tetapi memiliki dampak yang besar. Pustakawan merupakan profesi yang bersinggungan dengan pengolahan informasi.

Informasi saat ini merupakan entitas utama dalam segala bidang, sehingga membuka akses untuk dapat memperoleh informasi yang relevan sangatlah diperlukan. Untuk itu pustakawan perlu meningkatkan kualitas dirinya dalam upaya mengikuti perkembangan informasi yang begitu cepat.

\section{Kesimpulan}

Media sosial sudah sangat melekat dengan kehidupan masyarakat saat ini. Hal ini menunjukkan bahwa animo masyarakat terhadap kebutuhan informasi juga meningkat. Sebenarnya hal ini merupakan hal yang baik. Sayangnya, karena media sosial merupakan salah satu arena untuk menyebarkan informasi, maka ada banyak informasi yang simpang siur. Media sosial sendiri memiliki efek yang besar dalam menggiring opini publik. Hal ini yang perlu diwaspadai. Masyarakat harus dapat melek informasi yang ada di media sosial supaya dapat menjadi konsumen media sosial yang kritis.

Literasi media sosial merupakan suatu keterampilan yang diperlukan untuk tetap dapat melakukan aktifitas ber-media sosial dengan aman. Pustakawan merupakan salah satu profesi yang dekat dengan urusan informasi. Pustakawan juga merupakan profesi yang dianggap paling memahami mengenai literasi informasi. Sehingga memberikan literasi media sosial kepada masyarakat merupakan salah satu tanggung jawab pustakawan.

\section{Daftar Pustaka}

APJII dan PusKaKom UI. 2015. Demografi Pengguna Internet Indonesia. Dalam CNN Indonesia. Diunduh dari http://www.cnnindonesia.com/teknologi/20150327134253-18842341/demografi-pengguna-internet-indonesia/

Bodnar, Jonathan dan Doshi, Ameet. 2011. Asking the Right Questions: a critique of facebook, social media, and libraries. Routledge taylor \& Francis Group. DOI: 10.1080/152 15228959.2011 .623594

Crook, Jay. 2012. Howard Rheingold's Five Media Literacies. Dalam Jaycrook.com. Diunduh dari http://www.jaycrook.com/jay/masters/Howard\%20Rheingold.pdf

Goodman, Stacey. 2014. Social Media Literacy: The Five Key Concepts. Dalam Edutopia. Diunduh dari http://www.edutopia.org/blog/social-media-five-key-concepts-stacey-goodman

Internet Live Stats. 2014 . Internet Users by Country (2014) . Dalam Internet Live Stats. Diunduh dari http://www.internetlivestats.com/internet-users-by-country/

Manchester Metropolitan University. 2011. Information Literacy: A Literature Review. Diunduh dari http://www.learnhigher.mmu.ac.uk/research/InfoLit-Literature-Review.pdf

Prihadi, Susetyo Dwi. 2015. Berapa Jumlah Pengguna Facebook dan Twitter di Indonesia?. Dalam CNN Indonesia. Diunduh dari http://www.cnnindonesia.com/teknologi/20150327061134185-42245/berapa-jumlah-pengguna-facebook-dan-twitter-di-indonesia/ 
Rao, K. Nageswara dan Babu, KH. 2001. Role of Librarian in Internet and World Wide Web Environment. Dalam Information Science. Diunduh dari http://inform.nu/Articles/Vol4/v4n1p025-034.pdf

Taylor \& Francis Online. 2014. We ask Librarians - how do you use social media?. Dalam Taylor \& Francis Online. Diunduh dari http://explore.tandfonline.com/lmt/taylor-francis-whitepaper-on-social-media-use-in-libraries-advice

Tripp, Lisa. 2011. Digital Youth, Libraries, and New Media Literacy. Routledge taylor \& Francis Group. DOI: 10.1080/ 02763877.2011.584842 